\title{
Colliding Epidemics and the Rise of Cryptococcosis
}

\author{
Christina C. Chang ${ }^{1,2}$ and Sharon C.-A. Chen ${ }^{3,4, *}$
}

Received: 7 October 2015; Accepted: 9 December 2015; Published: 23 December 2015

Academic Editor: John R. Perfect

1 Department of Infectious Diseases, Alfred Hospital, Monash University, Melbourne 3181, Australia; christina.chang@monash.edu

2 HIV Pathogenesis Programme, University of KwaZulu Natal, Durban 4001, South Africa

3 Marie Bashir Institute for Emerging Infectious Diseases and Biosecurity, University of Sydney, Sydney 2145, Australia

4 Centre for Infectious Diseases and Microbiology Laboratory Services, ICPMR—Pathology West, Westmead Hospital, Sydney 2145, Australia

* Correspondence: sharon.chen@health.nsw.gov.au; Tel.: +61-2-9845-6255; Fax: +61-2-9893-8659

\begin{abstract}
Discovered more than 100 years ago as a human pathogen, the Cryptococcus neoformans-Cryptococcus gattii (C. neoformans-C. gattii) complex has seen a large global resurgence in its association with clinical disease in the last 30 years. First isolated in fermenting peach juice, and identified as a human pathogen in 1894 in a patient with bone lesions, this environmental pathogen has now found niches in soil, trees, birds, and domestic pets. Cryptococcosis is well recognized as an opportunistic infection and was first noted to be associated with reticuloendothelial cancers in the 1950s. Since then, advances in transplant immunology, medical science and surgical techniques have led to increasing numbers of solid organ transplantations (SOT) and hematological stem cell transplantations being performed, and the use of biological immunotherapeutics in increasingly high-risk and older individuals, have contributed to the further rise in cryptococcosis. Globally, however, the major driver for revivification of cryptococcosis is undoubtedly the HIV epidemic, particularly in Sub-Saharan Africa where access to care and antiretroviral therapy remains limited and advanced immunodeficiency, poverty and malnutrition remains the norm. As a zoonotic disease, environmental outbreaks of both human and animal cryptococcosis have been reported, possibly driven by climate change. This is best exemplified by the resurgence of $C$. gattii infection in Vancouver Island, Canada, and the Pacific Northwest of the United States since 1999. Here we describe how the colliding epidemics of HIV, transplantation and immunologics, climate change and migration have contributed to the rise of cryptococcosis.
\end{abstract}

Keywords: cryptococcosis; epidemiology; history; HIV; transplantation; outbreaks

\section{Introduction}

The history and biology of Cryptococcus neoformans (C. neoformans), now recognised as a species complex (the Cryptococcus neoformans-Cryptococcus gatti (C. gattii) complex), is detailed in an authoritative text by Casadavell and Perfect [1]. In the early 1990s, there were a smattering of reports of human and animal infection caused by Cryptococcus, including in the brain, lungs, skin and bone of humans, and of experimental infections in laboratory animals (reviewed in [1]). The introduction of corticosteroid therapy for various conditions and its association with such therapy with lymphoproliferative disorders stamped cryptococcosis as an opportunistic infection.

However, prior to 1981, cryptococcosis was a relatively rare condition (500-1000 cases a year in the United States (USA)) but with the onset of the HIV epidemic, 1200 cases of cryptococcosis were observed in New York City alone in 1991 [1]. Indeed, during this period, cryptococcal meningitis (CM) 
surpassed the combined numbers of all other causes of meningitis [1] and became the focus of intense research. The risks of cryptococcosis in patients who are immunosuppressed for reasons other than HIV / AIDS has also been of increasing interest. The spectrum of these patient groups is diverse, and includes patients with T-cell defects, hypogammaglobulinemia, transplant recipients and autoimmune conditions such as sarcoidosis and systemic lupus erythematosus. Prognosis of cryptococcosis was dismal in the early 1900s - with the exception of surgical removal of localized spinal lesions - until the antifungal agent, amphotericin B, was introduced in the late 1950s, which provided the first effective therapy against cryptococcosis. Today, both amphotericin B formulations and azole antifungals remain the mainstay of therapy.

\section{Cryptococcosis in Association with Malignancy and Autoimmune Diseases}

While the Scottish physician John Bennett and pathologist, Rudolph Virchow are often variously ascribed as the discoverers of leukemia, in fact the first description may be more accurately attributed to Peter Cullen in 1810, who described a 35 year old man with fevers and abdominal pain with milky blood, who he managed with "blood-letting" [2]. However, it was Bennett who in 1845 was the first to recognize that this "suppuration of the blood" was a primary disorder of the blood and later the condition was termed "weisses blood" and "leukemia" by Rudolph Virchow (reviewed in [2]). Hints of Cryptococcus spp. being an opportunistic pathogen occurring in patients with leukemia and other immunocompromised hosts arose with the first report of cryptococcosis (then cystic blastomyces or torulosis) in a patient with Hodgkin's disease [3]. Interestingly, the authors inoculated guinea pigs with the spinal fluid collected from this patient intraperitoneally, intranasally and subcutaneously, and demonstrated this led to weight loss and death [3]. Cerebral infection with Cryptococcus was further demonstrated on autopsy after infection by the latter two routes [3].

In Gendel's review of 165 patients with cryptococcosis (then torulosis), Hodgkin's disease was coincident in $14(8.5 \%)$ [4]. Of note, during this time, due to the propensity of cryptococci being recovered from enlarged lymph nodes, the notion of Cryptococcus as a cause of Hodgkin's disease was posed [4]. An astute Dubin in 1947 suggested instead that a weakened immune system is a factor for the development of multiple concurrent infections in patients with Hodgkin's disease [5]. In 1951, Collins et al. surmised a clear link between malignant reticulendothelial neoplasia (not only limited to Hodgkin's disease) and cryptococcosis from his detailed review of 243 patients with cryptococcosis [6].

Kaplan et al. then followed with a comprehensive account of cryptococcal infection occurring in patients with neoplastic disease at Memorial Sloan Kettering Cancer Centre between 1956 and 1972 [7]. Forty-seven patients were diagnosed with cryptococcosis by culture or histopathology over 17 years, at an average of 2-4 cases a year [7]. Patients with chronic lymphocytic leukemia (CLL), Hodgkins's disease, chronic myelocytic leukemia (CML) and multiple myeloma (MM) had the highest incidence of infection with rates of 24.3, 13.3, 10.9 and 6.9 per 1000 cases and, notably, only three patients had solid tumors [7]. Of the 23 patients who underwent autopsy, Cryptococcus was demonstrated in the central nervous system (CNS) in 20 patients, lungs-14, kidneys-six, spleen-five, lymph node - three, adrenals - two and one each of prostrate, thyroid, heart, pancreas and pericardium [7]. Of the 41 patients with neoplastic disease, 28 died within 60 days, despite amphotericin B being available to treat infection in the majority of cases [7]. Other infections include herpes zoster, tuberculosis (TB), nocardiosis, Pneumocystis and listeriosis, suggesting these patients were concurrently susceptible to intracellular pathogens [7].

Later, cryptococcosis became recognized as a common co-infection in multiple other immunodeficient states including autoimmune diseases and those with apparently normal immune status. These include the first cases of cryptococcosis in relation with sarcoidosis [8], with SLE [9], and in association with the use of steroids popularized in the 1950s [10,11]. Here, experiments using cryptococcal polysaccharide to stimulate white cells were also performed to refute Cryptococcus as the cause of these autoimmune phenomena [9]. Recently, a case of cryptococcosis was also reported in the setting of HyperIgM syndrome $[9,12]$ and in a patient with a known "Jak3" gene mutation 
with severe combined immunodeficiency [13], raising an alert for physicians managing patients with primary immunodeficiencies.

\section{The Rise of Transplantation and Transplant Immunology}

Peter Medawar's discovery of an immunological basis of graft rejection led us to the fundamental tenets of transplant immunology that a graft recipient reacts "against the graft" and will require immunosuppression for prolonged periods of time [14,15]. To this end, the ability of corticosteroid drugs to reduce rejection in animal models launched the idea of chemotherapeutic modulation of the human immune system (reviewed in [16]). Later, the development of purine and pyrimidine analogues including azathioprine and methotrexate [17] and cyclosporine, led to their successful use in cadaveric human renal transplants [18] and over the ensuing years, cyclosporine in particular, became the cornerstone of human transplantation. Since then, we have seen the development of newer drugs including Mycophenolate mofetil, tacrolimus [19] and Siroliumus [20], which have become key immunosuppressants in modern transplantation.

Surgical expertise has also contributed significantly to the pursuit for the perfect transplantation, including the first attempted kidney transplant in humans in 1906, the first successful renal transplantation (between identical twins) in 1954 [21], the first bone marrow transplant in 1957 [22,23], the first liver transplant in 1963 (reviewed in [24]), the first heart transplant in 1968 [22,23], the first heart-lung transplant in 1981 [22,23] and the first human allogeneic islet cell transplantation in 2000 [25]. Each patient group and transplant type mandates for lifelong, immunosuppression regimens with attendant lifelong risks for opportunistic infections including cryptococcosis. The looming possibility of porcine islet cell transplants from genetically-engineered pigs will bring new challenges [26]. The rapid progress in surgical techniques, organ preservation techniques, and newer effective immunosuppressants has contributed to an exponential growth in the number of transplantations. In 2012, the Global Observatory of Donation and Transplantation (GODT) reported at least 112,700 SOTS (a rise of $1.8 \%$ from 2011) with at least 77,800 renal transplants in a staggering 101 countries and at least 23,986 liver transplants in 68 countries [27]. These numbers are expected to rise with an expected rise in opportunistic infections.

This is well illustrated by the rising incidence of cryptococcosis in transplant recipients $[27,28]$, largely driven by reactivation disease secondary to immunosuppression, though primary (de novo) infection via inhalation also occurs. Equally, donor-derived cryptococcosis has also been reported [29,30]. Of 52 SOT recipients with cryptococcosis described by Davis in 2009, organs transplanted included kidney $(51.9 \%)$, liver $(23.1 \%)$, lung $(11.5 \%)$, heart (7.7.\%), kidney-liver (1.9\%), heart-lung $(1.9 \%)$ and liver-pancreas-small bowel (1.9\%) [28]. More recent reports of cryptococcosis post-SOT include those post-renal transplants [31-33], liver transplant [34], post-heart transplant [35], post-lung transplant [35,36] and a rare case of cryptococcosis post-autologous stem cell transplant [37]. While the majority present with $\mathrm{CM}$, pulmonary infection and cutaneous cryptococcosis have also been reported [38,39].

Further, immune reconstitution inflammatory syndrome (IRIS) occurring in the setting of transplants is now a key area of research [40-42] with paradoxical cryptococcosis-associated immune reconstitution inflammatory syndrome (C-IRIS) occurring in $~ 14 \%$ of SOT-recipients who developed cryptococcosis at a median of 17 months post-transplant [41]. C-IRIS has been reported post kidney, liver, heart and kidney-liver transplant [41,42]. Patients with transplant-C-IRIS compared to those without C-IRIS, are more likely to have CNS involvement and disseminated disease at baseline and are associated with increased rates of discontinuation of calcineurin inhibitors [43].

\section{Cryptococcosis and HIV}

The HIV epidemic has undoubtedly been the greatest, most transformative challenge to global health in recent decades. Along with the first reports of Kaposi's sarcoma in New York in 1981 and the discovery of the HIV virus in 1983 [17], CM became a common occurrence in American cities, to a 
point where it surpassed all other causes of meningitis combined. Recognized as an AIDS-defining illness (ADI) and often presenting as the first ADI, the lethality of advanced HIV and CM co-infection galvanized clinicians and researchers to focus on the delivery of antifungal therapy and management of raised intracranial pressure. Over the last 30 years, research in cryptococcosis-HIV co-infection has re-energized the field of cryptococcosis and Cryptococcus leading to nearly 10,000 research papers in this area of co-infection, and the recent creation of an international AIDS-Mycoses interest group.

In 2009, Park et al. reported an estimated million cases of CM occurring globally, of which two-thirds died within three months [44]. Not surprisingly, Sub-Saharan Africa bears $>80 \%$ of these deaths [44], where the estimated number of deaths due to CM exceeds the number due to TB, and is behind only to malaria, diarrheal illnesses and childhood-cluster diseases [44]. More specifically, CM accounts for up to $20 \%$ of early deaths in HIV cohorts in Sub-Saharan Africa [45] and a history of CM is a strong predictor of post-antiretroviral therapy (ART) mortality [46].

A recent retrospective study of sera collected over the last 20 years showed a $2.9 \%$ prevalence rate of cryptococcal antigenemia in patients with advanced HIV in the U.S. (McKenney, et al. 2015, [47]). The arrival of ART stemmed the tide of HIV-related opportunistic infections, and epidemiological reports showed a clear reversal of the incidence of cryptococcosis in the United States in the early 2000s [48]. With the introduction of ART, the United States has seen a steady $(5.8 \%)$ decline of cryptococcosis incidence, dropping to 1827 hospitalizations in 2009 nationwide [49]. The critical importance of ART in the management of HIV-CM co-infection is starkly illustrated in a paper from Zambia, where in an era without ART, all 230 patients with cryptococcosis died [50]. Distressingly, the median survival was only 19 days in those who received $200 \mathrm{mg}$ of fluconazole daily and 10 days in those without access to any antifungal therapy [50]. All patients were dead at seven weeks when left untreated, and of those receiving fluconazole, none survived beyond 24 weeks [50].

Building on the pioneering work of John Bennett in the 1970s [50,51], van de Horst et al. performed a landmark trial in the era of HIV, published in 1997 [52] on which the current Infectious Diseases Society of America (IDSA) guidelines [53] are based. This multicenter, randomized, double-blinded trial studied $306 \mathrm{HIV}$-infected patients with CM and demonstrated that (i) the addition of $100 \mathrm{mg} / \mathrm{kg} /$ day 5-flucytosine (5-FC) to $1 \mathrm{mg} / \mathrm{kg} /$ day amphotericin B deoxycholate had higher mycological clearance at two weeks than amphotericin B deoxycholate alone and (ii) that fluconazole $200 \mathrm{mg}$ daily was superior to Itraconazole $200 \mathrm{mg}$ twice daily as consolidation therapy. Combination of amphotericin B and 5-FC for $\mathrm{CM}$ recently received the ultimate randomized controlled trial validation of conferring improved survival, in a large study of 299 patients [54].

Other smaller but equally important studies in HIV-CM co-infection over the last 20 years have been led by Thomas Harrison's [55-59], David Boulware's [60-63] and Peter Pappas's [64] research groups based in Thailand, South Africa and Uganda, respectively. These clinical studies have compared antifungal therapy regimens and their route of administration [55,57], the role of adjuvant therapy $[55,58,65]$, management of intracranial pressure $[55,58,66,67]$ and the role of timing of ART commencement in the setting of active CM [62].

About $25 \%-30 \%$ of HIV-CM co-infected patients commencing ART develop C-IRIS [68,69] where patients represent with a flare of cryptococcal disease despite being on adequate ART and antifungal therapy. This is associated with repeated hospitalizations and increased morbidity and mortality. Increasing numbers of immunological studies in HIV-CM co-infection are being published as researchers attempt to understand the immunopathogenesis of HIV-CM co-infection and C-IRIS [61,70-73]. Just as HIV has challenged, yet also ironically strengthened, health systems globally, the scourge of HIV-CM co-infection has prompted research and care of CM in resource-limited settings which has, in turn, led to many insights applicable to other HIV co-infections.

All that said, in 2014, an estimated 36.9 million persons live with HIV globally of which 25.8 million reside in Sub-Saharan Africa [74]). Two million new HIV infections were reported in 2014 [74]. Overall, this equates to roughly 5600 new diagnoses per day, of which 600 occur in children [74]. While the 
last 30 years of HIV research has brought about much triumph, these figures highlight the continued challenge we face and the need for continued vigor and commitment to improving healthcare.

\section{Environmental Outbreaks}

Of more than 1.5 million species of fungi since their emergence 1.6 million years ago, only $<0.02 \%$ are associated with human infection, of which only a few are thermo-tolerant (i.e., able to grow at mammalian and higher temperatures) [75]. The ability of Cryptococcus spp. to grow optimally at human body temperatures $\left(37^{\circ} \mathrm{C}\right)$ is key to its virulence, and one of many reasons for its success as a human pathogen [76]. Intriguingly, transplant recipients from the southern United States have higher rates of cutaneous cryptococcosis compared to patients from other regions, even after controlling for confounders [39], though the mechanism for this remains unclear.

Climate change, global warming, natural disasters, pathogen evolution and shifts in host and vector populations may alter and pose new threats to the public $[75,77,78]$. The emergence of $C$. gatt $i$ in temperate climates, first coming to attention during the outbreak of $C$. gattii infections on Vancouver Island, British Columbia in 1999, is particularly illustrative. Previously thought to be restricted to tropical and subtropical climates, e.g., Central Africa, Cambodia, Thailand, Vietnam, Brazil, Australia, Hawaii and southern California [79], Stephen et al. [80], in 2002, reported a spike from the typical expectation of 4-6 cases a year, to 45 confirmed cases in animals and 50 in humans. Of the 45 infected animals, all but seven resided on the east coast of Vancouver Island and infected populations not only included cats and dogs, but also porpoises, ferrets and llamas [80]. Only three of the animals had received prior prednisolone [80].

This was followed by a comprehensive epidemiological study from 1999 to 2007 by Galanis et al. [81]. They reported a steady increase from six human cases per year in British Columbia in 1999, to 38 cases in 2006, totaling 218 cases, of which 73.9\% resided on Vancouver Island and only $38 \%$ had an identifiable immunodeficiency [81]. While the incidence on Vancouver Island plateaued in 2002, the incidence on the North American mainland has increased [81]. Of note, C. gattii isolates of the molecular type (or genotype) VGII (subtype VGIIa and VGIIb) was found in $86.3 \%$ of confirmed cases [81] and recent coalescence gene genealogy analysis showed that this genotype is derived from ancient dispersal of $C$. gattii lineages originating from the Amazon rainforest [82]. From 2004 to 2010, 60 cases from the Pacific Northwest United States were reported to the Centre of Disease Control (CDC) of United States [83]. Following which, from 2009 to 2012, 25 human cases have been reported in eight non-Pacific Northwest states suggesting continued spread of this clonal strain with further subtyping studies delineating a novel subtype (VGIIc) not yet found outside the United States [84].

An appreciation of the distribution of molecular types by geographic region is central to the understanding of the current epidemiology of human infection, detailed here for C. gattii in Table 1 . Genotyping of infective strains is particularly interesting in the setting of outbreaks and travel, both for tracking the origin of the isolate and for epidemiological purposes as illustrated by a Dutch returned traveler from Vancouver Island who acquired a C. gattii VGIlb infection [85]. Similarly, cryptococcal infections caused by molecular types VGIII and VGIV diagnosed in patients in Europe, have been elegantly linked to their prior exposure to regions in Africa [86].

Genotyping also allows recognition of strain evolution in the environment, illustrated by a novel local acquisition of VGIIa in a patient from Tokyo, where VGIIa had not previously been reported [87]. The impact of strain evolution, human travel, migration and environmental change in this already globalized world, on human and animal cryptococcosis will require continued, coordinated international epidemiological surveillance and response. 
Table 1. Molecular types of Cryptococcus gattii: broad distribution by selected regions *.

\begin{tabular}{lcccc}
\hline \multirow{2}{*}{ Region } & \multicolumn{4}{c}{ Genotype (\% Total Strains) } \\
\cline { 2 - 5 } & VGI & VGII & VGIII & VGIV \\
\hline North America & 11 & 60 & 15 & 4 \\
South America & 12 & 69 & 15 & 4 \\
Europe & 70 & 30 & - & - \\
Africa & 11 & 1 & 2 & 86 \\
Asia & 73 & 19 & 5 & 3 \\
Australasia & 65 & 31 & 7 & - \\
\hline
\end{tabular}

* Adapted from Chen et al. [88].

\section{Conclusions}

Progress in medical science particularly in the management of autoimmune illnesses, malignancy and transplantation, together with the ongoing burden and threat of HIV globally and the imminent peril of climate change and environmental outbreaks have combined to chart the history and rise of cryptococcosis over the last 100 years. Sadly, 100 years later, mortality rates remain unacceptably high, particularly in resource-limited settings. Earlier diagnosis and treatment of cryptococcosis, newer antifungal therapy options and a better understanding of host-pathogen immuno-genetic determinants of cryptococcosis are required. The current explosion in the development of newer immunosuppressants and biologic agents, and the emergence of infectious diseases such as Ebola disease leading to an undetermined state of chronic immunosuppression in resource-deplete areas endemic for HIV and cryptococcosis, will test us further. What the future holds and how clinicians and researchers rise to the evolving challenges is to be determined.

Conflicts of Interest: The authors declare no conflict of interest.

\section{References}

1. Casadevall, A.; Perfect, J.R. Introduction to the Pathogen. In Cryptococcus Neoformans; American Society for Microbiology (ASM) Press: Washington, DC, USA, 1998; pp. 1-27.

2. Kampen, K.R. The discovery and early understanding of leukemia. Leuk. Res. 2012, 36, 6-13. [CrossRef] [PubMed]

3. Freeman, W.; Weidman, F.D. Cystic blastomycosis of the cerebral gray matter. Arch. Neurol. Psychiatry 1923, 9, 589-603. [CrossRef]

4. Gendel, B.R.; Ende, M.; Norman, S.L. Cryptococcosis: A review with special reference to apparent association with Hodgkin's disease. Am. J. Med. 1950, 9, 343-355. [CrossRef]

5. Dubin, I.N. The poverty of the immunological mechanism in patients with Hodgkin's disease. Ann. Intern. Med. 1947, 27, 898-913. [PubMed]

6. Collins, V.P.; Gellhorn, A.; Trimble, J.R. The coincidence of cryptococcosis and disease of the reticulo-endothelial and lymphatic systems. Cancer 1951, 4, 883-889. [CrossRef]

7. Kaplan, M.H.; Rosen, P.P.; Armstrong, D. Cryptococcosis in a cancer hospital: Clinical and pathological correlates in forty-six patients. Cancer 1977, 39, 2265-2274. [CrossRef]

8. Lepow, H.; Rubenstein, L.; Chu, F.; Shandra, J. A case of Cryptococcus neoformans meningoencephalitis complicating Boeck's sarcoid. Pediatrics 1957, 19, 377-386. [PubMed]

9. Pariser, S.; Littman, M.L.; Duffy, J.L. Cryptococcal meningo-encephalitis associated with systemic lupus erythematosus. J. Mt. Sinai Hosp. N. Y. 1961, 28, 550-561. [PubMed]

10. Linden, I.H.; Steffen, C.G. Pulmonary cryptococcosis. Am. Rev. Tuberc. 1954, 69, 116-120. [PubMed]

11. Goldstein, E.; Rambo, O.N. Cryptococcal infection following steroid therapy. Ann. Intern. Med. 1962, 56, 114-120. [CrossRef] [PubMed] 
12. Malheiro, L.; Lazzara, D.; Xerinda, S.; Pinheiro, M.D.; Sarmento, A. Cryptococcal meningoencephalitis in a patient with hyper immunoglobulin M (IgM) syndrome: A case report. BMC Res. Notes 2014, 7. [CrossRef] [PubMed]

13. Alsum, Z.; Al-Saud, B.; Al-Ghonaium, A.; Bin Hussain, I.; Alsmadi, O.; Al-Mousa, H.; Ayas, M.; Al-Dhekri, H.; Arnaout, R.; Al-Muhsen, S. Disseminated cryptococcal infection in patient with novel JAK3 mutation severe combined immunodeficiency, with resolution after stem cell transplantation. Pediatr. Infect. Dis. J. 2012, 31, 204-206. [CrossRef] [PubMed]

14. Muller-Ruchholtz, W. Glances at the history of transplantation immunology. Transplant. Proc. 1999, 31, 1443-1451. [CrossRef]

15. Starzl, T.E.; Zinkernagel, R.M. Transplantation tolerance from a historical perspective. Nat. Rev. Immunol. 2001, 1, 233-239. [CrossRef] [PubMed]

16. Russell, P.S.; Monaco, A.P. The biology of tissue transplantation. N. Engl. J. Med. 1964, $271,664-671$. [CrossRef] [PubMed]

17. The Nobel Prize in Physiology or Medicine. 2015. Available online: http://www.nobelprize.org/ nobel_prizes/medicine/laureates / (accessed on 3 October 2015).

18. Calne, R.Y.; White, D.J.; Thiru, S.; Evans, D.B.; McMaster, P.; Dunn, D.C.; Craddock, G.N.; Pentlow, B.D.; Rolles, K. Cyclosporin A in patients receiving renal allografts from cadaver donors. Lancet 1978, 2, 1323-1327. [CrossRef]

19. Kino, T.; Hatanaka, H.; Hashimoto, M.; Nishiyama, M.; Goto, T.; Okuhara, M.; Kohsaka, M.; Aoki, H.; Imanaka, H. FK-506, a novel immunosuppressant isolated from a Streptomyces. I. Fermentation, isolation, and physico-chemical and biological characteristics. J. Antibiot. 1987, 40, 1249-1255. [CrossRef] [PubMed]

20. Vezina, C.; Kudelski, A.; Sehgal, S.N. Rapamycin (AY-22,989), a new antifungal antibiotic. I. Taxonomy of the producing streptomycete and isolation of the active principle. J. Antibiot. 1975, 28, 721-726. [CrossRef] [PubMed]

21. Schlich, T. The origins of organ transplantation. Lancet 2011, 378, 1372-1373. [CrossRef]

22. Linden, P.K. History of solid organ transplantation and organ donation. Crit. Care Clin. 2009, 25, $165-184$. [CrossRef] [PubMed]

23. Watson, C.J.; Dark, J.H. Organ transplantation: Historical perspective and current practice. Br. J. Anaesth. 2012, 108 (Suppl. S1), i29-i42. [CrossRef] [PubMed]

24. Van Thiel, D.H.; Makowka, L.; Starzl, T.E. Liver transplantation: Where it's been and where it's going. Gastroenterol. Clin. N. Am. 1988, 17, 1-18. [CrossRef]

25. Shapiro, A.M.; Lakey, J.R.; Ryan, E.A.; Korbutt, G.S.; Toth, E.; Warnock, G.L.; Kneteman, N.M.; Rajotte, R.V. Islet transplantation in seven patients with type 1 diabetes mellitus using a glucocorticoid-free immunosuppressive regimen. N. Engl. J. Med. 2000, 343, 230-238. [CrossRef] [PubMed]

26. Park, C.G.; Bottino, R.; Hawthorne, W.J. Current status of islet xenotransplantation. Int. J. Surg. 2015. [CrossRef] [PubMed]

27. Global Observatory on Donations and Transplantation. 2015. Available online: http:/ /www.transplant-observatory.org/Pages/home.aspx (accessed on 3 October 2015).

28. Davis, J.A.; Horn, D.L.; Marr, K.A.; Fishman, J.A. Central nervous system involvement in cryptococcal infection in individuals after solid organ transplantation or with AIDS. Transpl. Infect. Dis. 2009, 11, $432-437$. [CrossRef] [PubMed]

29. Baddley, J.W.; Schain, D.C.; Gupte, A.A.; Lodhi, S.A.; Kayler, L.K.; Frade, J.P.; Lockhart, S.R.; Chiller, T.; Bynon, J.S., Jr.; Bower, W.A. Transmission of Cryptococcus neoformans by Organ Transplantation. Clin. Infect. Dis. 2011, 52, e94-e98. [CrossRef] [PubMed]

30. Sun, H.Y.; Alexander, B.D.; Lortholary, O.; Dromer, F.; Forrest, G.N.; Lyon, G.M.; Somani, J.; Gupta, K.L.; del Busto, R.; Pruett, T.L.; et al. Unrecognized pretransplant and donor-derived cryptococcal disease in organ transplant recipients. Clin. Infect. Dis. 2010, 51, 1062-1069. [CrossRef] [PubMed]

31. Khan, A.; El-Charabaty, E.; El-Sayegh, S. Fungal infections in renal transplant patients. J. Clin. Med. Res. 2015, 7, 371-378. [CrossRef] [PubMed]

32. Santos, T.; Aguiar, B.; Santos, L.; Romaozinho, C.; Tome, R.; Macario, F.; Alves, R.; Campos, M.; Mota, A. Invasive Fungal Infections after Kidney Transplantation: A Single-center Experience. Transplant. Proc. 2015, 47, 971-975. [CrossRef] [PubMed] 
33. Cicora, F.; Petroni, J.; Formosa, P.; Roberti, J. A rare case of Cryptococcus gattii pneumonia in a renal transplant patient. Transpl. Infect. Dis. 2015, 17, 463-466. [CrossRef] [PubMed]

34. Singh, N.; Sifri, C.D.; Silveira, F.P.; Miller, R.; Gregg, K.S.; Huprikar, S.; Lease, E.D.; Zimmer, A.; Dummer, J.S.; Spak, C.W. Cryptococcosis in Patients with Cirrhosis of the Liver and Posttransplant Outcomes. Transplantation 2015, 99, 2132-2141. [CrossRef] [PubMed]

35. Farber, S.A.; Micheletti, R.G. Cryptococcal meningitis presenting with headache and a pustular eruption in a heart transplant patient. Transpl. Infect. Dis. 2015, 17, 716-718. [CrossRef] [PubMed]

36. Dall Bello, A.G.; Severo, C.B.; Schio, S.; Severo, L.C. First reported case of cellulitis due to Cryptococcus gattii in lung transplantation recipient: A case report. Dermatol. Online J. 2013, 19, 20395. [PubMed]

37. Chaaban, S.; Wheat, L.J.; Assi, M. Cryptococcal meningitis post autologous stem cell transplantation. Transpl. Infect. Dis. 2014, 16, 473-476. [CrossRef] [PubMed]

38. Biancheri, D.; Kanitakis, J.; Bienvenu, A.L.; Picot, S.; Morelon, E.; Faure, M.; Euvrard, S. Cutaneous cryptococcosis in solid organ transplant recipients: Epidemiological, clinical, diagnostic and therapeutic features. Eur. J. Dermatol. 2012, 22, 651-657. [PubMed]

39. Osawa, R.; Alexander, B.D.; Forrest, G.N.; Lyon, G.M.; Somani, J.; del Busto, R.; Pruett, T.L.; Sifri, C.D.; Limaye, A.P.; Klintmalm, G.B. Geographic differences in disease expression of cryptococcosis in solid organ transplant recipients in the United States. Ann. Transplant. 2010, 15, 77-83. [PubMed]

40. Singh, N.; Lortholary, O.; Alexander, B.D.; Gupta, K.L.; John, G.T.; Pursell, K.; Munoz, P.; Klintmalm, G.B.; Stosor, V.; del Busto, R. An immune reconstitution syndrome-like illness associated with Cryptococcus neoformans infection in organ transplant recipients. Clin. Infect. Dis. 2005, 40, 1756-1761. [CrossRef] [PubMed]

41. Sun, H.Y.; Singh, N. Immune reconstitution inflammatory syndrome in non-HIV immunocompromised patients. Curr. Opin. Infect. Dis. 2009, 22, 394-402. [CrossRef] [PubMed]

42. Sun, H.Y.; Singh, N. Opportunistic infection-associated immune reconstitution syndrome in transplant recipients. Clin. Infect. Dis. 2011, 53, 168-176. [CrossRef] [PubMed]

43. Sun, H.Y.; Alexander, B.D.; Huprikar, S.; Forrest, G.N.; Bruno, D.; Lyon, G.M.; Wray, D.; Johnson, L.B.; Sifri, C.D.; Razonable, R.R. Predictors of immune reconstitution syndrome in organ transplant recipients with cryptococcosis: Implications for the management of immunosuppression. Clin. Infect. Dis. 2015, 60, 36-44. [CrossRef] [PubMed]

44. Park, B.J.; Wannemuehler, K.A.; Marston, B.J.; Govender, N.; Pappas, P.G.; Chiller, T.M. Estimation of the current global burden of cryptococcal meningitis among persons living with HIV/AIDS. AIDS 2009, 23, 525-530. [CrossRef] [PubMed]

45. Lawn, S.D.; Harries, A.D.; Anglaret, X.; Myer, L.; Wood, R. Early mortality among adults accessing antiretroviral treatment programmes in sub-Saharan Africa. AIDS 2008, 22, 1897-1908. [CrossRef] [PubMed]

46. Ojikutu, B.O.; Zheng, H.; Walensky, R.P.; Lu, Z.; Losina, E.; Giddy, J.; Freedberg, K.A. Predictors of mortality in patients initiating antiretroviral therapy in Durban, South Africa. S. Afr. Med. J. 2008, 98, 204-208. [PubMed]

47. McKenney, J.; Smith, R.M.; Chiller, T.M.; Detels, R.; French, A.; Margolick, J.; Klausner, J.D.; Centers for Disease Control and Prevention. Prevalence and Correlates of Cryptococcal Antigen Positivity Among AIDS Patients-United States, 1986-2012. Morb. Mortal. Wkly. Rep. 2014, 63, 585-587.

48. Mirza, S.A.; Phelan, M.; Rimland, D.; Graviss, E.; Hamill, R.; Brandt, M.E.; Gardner, T.; Sattah, M.; de Leon, G.P.; Baughman, W.; Hajjeh, R.A. The changing epidemiology of cryptococcosis: An update from population-based active surveillance in 2 large metropolitan areas, 1992-2000. Clin. Infect. Dis. 2003, 36, 789-794. [CrossRef] [PubMed]

49. Pyrgos, V.; Seitz, A.E.; Steiner, C.A.; Prevots, D.R.; Williamson, P.R. Epidemiology of cryptococcal meningitis in the U.S.: 1997-2009. PLoS ONE 2013, 8, e56269. [CrossRef] [PubMed]

50. Mwaba, P.; Mwansa, J.; Chintu, C.; Pobee, J.; Scarborough, M.; Portsmouth, S.; Zumla, A. Clinical presentation, natural history, and cumulative death rates of 230 adults with primary cryptococcal meningitis in Zambian AIDS patients treated under local conditions. Postgrad. Med. J. 2001, 77, 769-773. [CrossRef] [PubMed]

51. Bennett, J.E.; Dismukes, W.E.; Duma, R.J.; Medoff, G.; Sande, M.A.; Gallis, H.; Leonard, J.; Fields, B.T.; Bradshaw, M.; Haywood, H. A comparison of amphotericin B alone and combined with flucytosine in the treatment of cryptoccal meningitis. N. Engl. J. Med. 1979, 301, 126-131. [CrossRef] [PubMed] 
52. Van der Horst, C.M.; Saag, M.S.; Cloud, G.A.; Hamill, R.J.; Graybill, J.R.; Sobel, J.D.; Johnson, P.C.; Tuazon, C.U.; Kerkering, T.; Moskovitz, B.L.; et al. Treatment of cryptococcal meningitis associated with the acquired immunodeficiency syndrome. National Institute of Allergy and Infectious Diseases Mycoses Study Group and AIDS Clinical Trials Group. N. Engl. J. Med. 1997, 337, 15-21. [CrossRef] [PubMed]

53. Perfect, J.R.; Dismukes, W.E.; Dromer, F.; Goldman, D.L.; Graybill, J.R.; Hamill, R.J.; Harrison, T.S.; Larsen, R.A.; Lortholary, O.; Nguyen, M.H. Clinical practice guidelines for the management of cryptococcal disease: 2010 update by the infectious diseases society of America. Clin. Infect. Dis. 2010, 50, 291-322. [CrossRef] [PubMed]

54. Day, J.N.; Chau, T.T.; Wolbers, M.; Mai, P.P.; Dung, N.T.; Mai, N.H.; Phu, N.H.; Nghia, H.D.; Phong, N.D.; Thai, C.Q.; et al. Combination antifungal therapy for cryptococcal meningitis. N. Engl. J. Med. 2013, 368, 1291-1302. [CrossRef] [PubMed]

55. Bicanic, T.; Wood, R.; Meintjes, G.; Rebe, K.; Brouwer, A.; Loyse, A.; Bekker, L.G.; Jaffar, S.; Harrison, T. High-dose amphotericin B with flucytosine for the treatment of cryptococcal meningitis in HIV-infected patients: A randomized trial. Clin. Infect. Dis. 2008, 47, 123-130. [CrossRef] [PubMed]

56. Bicanic, T.; Muzoora, C.; Brouwer, A.E.; Meintjes, G.; Longley, N.; Taseera, K.; Rebe, K.; Loyse, A.; Jarvis, J.; Bekker, L.G.; et al. Independent association between rate of clearance of infection and clinical outcome of HIV-associated cryptococcal meningitis: Analysis of a combined cohort of 262 patients. Clin. Infect. Dis. 2009, 49, 702-709. [CrossRef] [PubMed]

57. Brouwer, A.E.; Rajanuwong, A.; Chierakul, W.; Griffin, G.E.; Larsen, R.A.; White, N.J.; Harrison, T.S. Combination antifungal therapies for HIV-associated cryptococcal meningitis: A randomised trial. Lancet 2004, 363, 1764-1767. [CrossRef]

58. Jarvis, J.N.; Meintjes, G.; Rebe, K.; Williams, G.N.; Bicanic, T.; Williams, A.; Schutz, C.; Bekker, L.G.; Wood, R.; Harrison, T.S. Adjunctive interferon-gamma immunotherapy for the treatment of HIV-associated cryptococcal meningitis: A randomized controlled trial. AIDS 2012, 26, 1105-1113. [CrossRef] [PubMed]

59. Jarvis, J.N.; Bicanic, T.; Loyse, A.; Namarika, D.; Jackson, A.; Nussbaum, J.C.; Longley, N.; Muzoora, C.; Phulusa, J.; Taseera, K. Determinants of Mortality in a Combined Cohort of 501 Patients with HIV-Associated Cryptococcal Meningitis: Implications for Improving Outcomes. Clin. Infect. Dis. 2014, 58, 736-745. [CrossRef] [PubMed]

60. Boulware, D.R.; Bonham, S.C.; Meya, D.B.; Wiesner, D.L.; Park, G.S.; Kambugu, A.; Janoff, E.N.; Bohjanen, P.R. Paucity of initial cerebrospinal fluid inflammation in cryptococcal meningitis is associated with subsequent immune reconstitution inflammatory syndrome. J. Infect. Dis. 2010, 202, 962-970. [CrossRef] [PubMed]

61. Boulware, D.R.; Meya, D.B.; Bergemann, T.L.; Wiesner, D.L.; Rhein, J.; Musubire, A.; Lee, S.J.; Kambugu, A.; Janoff, E.N.; Bohjanen, P.R. Clinical features and serum biomarkers in HIV immune reconstitution inflammatory syndrome after cryptococcal meningitis: A prospective cohort study. PLoS Med. 2010, 7, e1000384. [CrossRef] [PubMed]

62. Boulware, D.R.; Meya, D.B.; Muzoora, C.; Rolfes, M.A.; Hullsiek, K.H.; Musubire, A.; Taseera, K.; Nabeta, H.W.; Schutz, C.; Williams, D.A.; et al. Timing of antiretroviral therapy after diagnosis of cryptococcal meningitis. N. Engl. J. Med. 2014, 370, 2487-2498. [CrossRef] [PubMed]

63. Meya, D.B.; Manabe, Y.C.; Castelnuovo, B.; Cook, B.A.; Elbireer, A.M.; Kambugu, A.; Kamya, M.R.; Bohjanen, P.R.; Boulware, D.R. Cost-effectiveness of serum cryptococcal antigen screening to prevent deaths among HIV-infected persons with a CD4+ cell count $\leqslant 100$ cells/ $\mu \mathrm{L}$ who start HIV therapy in resource-limited settings. Clin. Infect. Dis. 2010, 51, 448-455. [CrossRef] [PubMed]

64. Pappas, P.G.; Chetchotisakd, P.; Larsen, R.A.; Manosuthi, W.; Morris, M.I.; Anekthananon, T.; Sungkanuparph, S.; Supparatpinyo, K.; Nolen, T.L.; Zimmer, L.O.; et al. A phase II randomized trial of amphotericin B alone or combined with fluconazole in the treatment of HIV-associated cryptococcal meningitis. Clin. Infect. Dis. 2009, 48, 1775-1783. [CrossRef] [PubMed]

65. Pappas, P.G.; Bustamante, B.; Ticona, E.; Hamill, R.J.; Johnson, P.C.; Reboli, A.; Aberg, J.; Hasbun, R.; Hsu, H.H. Recombinant interferon-gamma $1 \mathrm{~b}$ as adjunctive therapy for AIDS-related acute cryptococcal meningitis. J. Infect. Dis. 2004, 189, 2185-2191. [PubMed]

66. Bicanic, T.; Brouwer, A.E.; Meintjes, G.; Rebe, K.; Limmathurotsakul, D.; Chierakul, W.; Teparrakkul, P.; Loyse, A.; White, N.J.; Wood, R.; Jaffar, S.; Harrison, T. Relationship of cerebrospinal fluid pressure, fungal burden and outcome in patients with cryptococcal meningitis undergoing serial lumbar punctures. AIDS 2009, 23, 701-706. [CrossRef] [PubMed] 
67. Rolfes, M.A.; Hullsiek, K.H.; Rhein, J.; Nabeta, H.W.; Taseera, K.; Schutz, C.; Musubire, A.; Rajasingham, R.; Williams, D.A.; Thienemann, F.; et al. The effect of therapeutic lumbar punctures on acute mortality from cryptococcal meningitis. Clin. Infect. Dis. 2014, 59, 1607-1614. [CrossRef] [PubMed]

68. Shelburne, S.A., III; Darcourt, J.; White, A.C., Jr.; Greenberg, S.B.; Hamill, R.J.; Atmar, R.L.; Visnegarwala, F. The role of immune reconstitution inflammatory syndrome in AIDS-related Cryptococcus neoformans disease in the era of highly active antiretroviral therapy. Clin. Infect. Dis. 2005, 40, 1049-1052. [CrossRef] [PubMed]

69. Chang, C.C.; Dorasamy, A.A.; Gosnell, B.I.; Elliott, J.H.; Spelman, T.; Omarjee, S.; Naranbhai, V.; Coovadia, Y.; Ndung'u, T.; Moosa, M.Y.; et al. Clinical and mycological predictors of Cryptococcosis-associated Immune reconstitution inflammatory syndrome (C-IRIS). AIDS 2013, 27, 2089-2099. [CrossRef] [PubMed]

70. Boulware, D.R.; Meya, D.B.; Bergemann, T. Inflammatory Biomarkers in Serum Predict HIV Immune Reconstitution Inflammatory Syndrome and Death after Cryptococcal Meningitis. In Proceedings of the 16th Conference on Retroviruses and Opportunistic Infections (CROI), Montreal, QC, Canada, 8-11 February 2009.

71. Chang, C.C.; Lim, A.; Omarjee, S.; Levitz, S.M.; Gosnell, B.I.; Spelman, T.; Elliott, J.H.; Carr, W.H.; Moosa, M.Y.; Ndung'u, T.; et al. Cryptococcosis-IRIS is associated with lower Cryptococcus-specific IFN-gamma responses before antiretroviral therapy but not higher T-cell responses during therapy. J. Infect. Dis. 2013, 208, 898-906. [CrossRef] [PubMed]

72. Chang, C.C.; Omarjee, S.; Lim, A.; Spelman, T.; Gosnell, B.I.; Carr, W.H.; Elliott, J.H.; Moosa, M.Y.; Ndung'u, T.; French, M.A.; et al. Chemokine levels and chemokine receptor expression in blood and the CSF of HIV-infected patients with cryptococcal meningitis and C-IRIS. J. Infect. Dis. 2013, 208, 1604-1612. [CrossRef] [PubMed]

73. Jarvis, J.N.; Casazza, J.P.; Stone, H.H.; Meintjes, G.; Lawn, S.D.; Levitz, S.M.; Harrison, T.S.; Koup, R.A. The phenotype of the Cryptococcus-specific $\mathrm{CD} 4^{+}$memory T-cell response is associated with disease severity and outcome in HIV-associated cryptococcal meningitis. J. Infect. Dis. 2013, 207, 1817-1828. [CrossRef] [PubMed]

74. UNAIDS 2014: Fact Sheet. 2015. Available online: http://www.unaids.org/en/resources/documents/2015/ 20150714_factsheet (accessed on 3 October 2015).

75. Garcia-Solache, M.A.; Casadevall, A. Global warming will bring new fungal diseases for mammals. MBio 2010, 1. [CrossRef] [PubMed]

76. Perfect, J.R. Cryptococcus neoformans: The yeast that likes it hot. FEMS Yeast Res. 2006, 6, 463-468. [CrossRef] [PubMed]

77. Raffa, R.B.; Eltoukhy, N.S.; Raffa, K.F. Implications of climate change (global warming) for the healthcare system. J. Clin. Pharm. Ther. 2012, 37, 502-504. [CrossRef] [PubMed]

78. Benedict, K.; Park, B.J. Invasive fungal infections after natural disasters. Emerg. Infect. Dis. 2014, 20, 349-355. [CrossRef] [PubMed]

79. Kwon-Chung, K.J.; Bennett, J.E. Epidemiologic differences between the two varieties of Cryptococcus neoformans. Am. J. Epidemiol. 1984, 120, 123-130. [PubMed]

80. Stephen, C.; Lester, S.; Black, W.; Fyfe, M.; Raverty, S. Multispecies outbreak of cryptococcosis on southern Vancouver Island, British Columbia. Can. Vet. J. 2002, 43, 792-794. [PubMed]

81. Galanis, E.; MacDougall, L.; Kidd, S.; Morshed, M. British Columbia Cryptococcus gattii Working Group. Epidemiology of Cryptococcus gattii, British Columbia, Canada, 1999-2007. Emerg. Infect. Dis. 2010, 16, 251-257. [CrossRef] [PubMed]

82. Hagen, F.; Ceresini, P.C.; Polacheck, I.; Ma, H.; van Nieuwerburgh, F.; Gabaldón, T.; Kagan, S.; Pursall, E.R.; Hoogveld, H.L.; van Iersel, L.J.; et al. Ancient dispersal of the human fungal pathogen Cryptococcus gattii from the Amazon rainforest. PLoS ONE 2013, 8, e71148. [CrossRef] [PubMed]

83. Centers for Disease Control and Prevention. Emergence of Cryptococcus gattii-Pacific Northwest, $2004-2010$. Ann. Emerg. Med. 2011, 57, 60-62.

84. Harris, J.R.; Lockhart, S.R.; Sondermeyer, G.; Vugia, D.J.; Crist, M.B.; D'Angelo, M.T.; Sellers, B.; Franco-Paredes, C.; Makvandi, M.; Smelser, C.; et al. Cryptococcus gattii infections in multiple states outside the US Pacific Northwest. Emerg. Infect. Dis. 2013, 19, 1620-1626. [CrossRef] [PubMed]

85. Hagen, F.; van Assen, S.; Luijckx, G.J.; Boekhout, T.; Kampinga, G.A. Activated dormant Cryptococcus gattii infection in a Dutch tourist who visited Vancouver Island (Canada): A molecular epidemiological approach. Med. Mycol. 2010, 48, 528-531. [CrossRef] [PubMed] 
86. Hagen, F.; Colom, M.F.; Swinne, D.; Tintelnot, K.; Latta, R.; Montagna, M.T.; Torres-Rodriguez, J.M.; Cogliati, M.; Velegraki, A.; Burggraaf, A.; et al. Autochthonous and dormant Cryptococcus gattii infections in Europe. Emerg. Infect. Dis. 2012, 18, 1618-1624. [CrossRef] [PubMed]

87. Okamoto, K.; Hatakeyama, S.; Itoyama, S.; Nukui, Y.; Yoshino, Y.; Kitazawa, T.; Yotsuyanagi, H.; Ikeda, R.; Sugita, T.; Koike, K. Cryptococcus gattii genotype VGIIa infection in man, Japan, 2007. Emerg. Infect. Dis. 2010, 16, 1155-1157. [CrossRef] [PubMed]

88. Chen, S.C.; Meyer, W.; Sorrell, T.C. Cryptococcus gattii infections. Clin. Microbiol. Rev. 2014, 27, 980-1024. [CrossRef] [PubMed] 